\title{
ISLAM AND THE CHALLENGE OF DIVERSITY AND PLURALISM: MUST ISLAM REFORM ITSELF?
}

\author{
Osman Bakar*
}

\begin{abstract}
This article seeks to present a counter view of the Western critique of contemporary Islam with specific reference to its treatment of the problem of diversity and pluralism. The prevailing Western view of Islam's experience of diversity and pluralism is that it has failed to positively respond to this important challenge of the modern world. The basic belief underlying this view is that Islam is incompatible with modernity, political democracy, and cultural diversity and pluralism, which are generally considered as the hallmarks of modern Western civilisation. According to this view, only a radically reformed Islam can come to terms with these Western achievements. The Western critique of contemporary Islam is discussed in the context of a post-September 11 world for the important reason that it was the September 11 tragedy that generated a new phase of Western interest in Islam and fresh calls for its reforms. An influential voice in this Western critique is Bernard Lewis who, in his decades of scholarship on Islam, has consistently argued for an Islamic reformation. This article seeks to provide a critical response to the Lewisian idea of Islamic reformation, especially concerning the issue of diversity and pluralism. It argues that a new Islamic understanding of diversity and pluralism is urgently needed in this century, but this can only come about through an authentic tajdid (renewal) that offers fresh interpretations of the religion without destroying its original soul, spirit and character.
\end{abstract}

\section{September 11: The West's New Scrutiny of Islam}

The total destruction of the twin towers of the World Trade Center in New York in the September 11, 2001 tragedy resulted in an historic 'explosion' in the realm of ideas. I am referring to a new explosion of Western interest in Islam and the Muslims in academic and scholarly circles, the business and media community, including popular talk-shows. The new interest in Islam as it has been previously is a twosided cultural phenomenon. There was the negative side of Western reactions and responses to the tragedy. One aspect of these negative phenomena is now popularly

* Professor Dato' Dr Osman Bakar is the Deputy CEO of the International Institute of Advanced Islamic Studies (IAIS) Malaysia. 
referred to as 'Islamophobia'. Parallel to the genuine interest to know more about Islam among many Americans and Europeans, which is a positive thing, are the growing anti-Islam sentiments in the same community, including the hate messages against Muslims as portrayed, for example, through caricatures of the Prophet Muhammad. Indeed, it may be claimed, that in the aftermath of September 11, we see yet another phase in the history of Western interest in things Islamic, which is more remarkable and significant than anything we have ever witnessed since the end of colonialism. In this new phase Islam emerges as an object of widespread inquisitiveness and fascination as well as an object of hate and ridicule. The extent to which the positive interest in Islam goes hand in hand with the negative portrayal of the religion, particularly its anti-Islam variety, is indeed unparalleled in the history of relations between Islam and the West. ${ }^{1}$

My main concern here is with that aspect of Western interest in Islam pertaining to the latter's modern experience with diversity and pluralism. Following the September 11 tragedy, many Westerners came to harbour the belief that Islam is inherently incompatible with modernity and that Muslims cannot live in peace with the non-Muslims in a pluralistic society, let alone have the ability to govern it. $^{2}$ To these Westerners, a Muslim destruction of such a monumental symbol of modern progress as the World Trade Center is ample proof that the Muslims cannot coexist peacefully with people of other cultures and civilisations. Not a few notable figures in America from among academia, the media, and political circles saw the attacks on both the nation's financial capital in New York and the political capital in Washington DC as an attack on Western civilisation itself. Bernard Lewis, ${ }^{3}$ a well-

1. For an early assessment of the impact of the September 11 tragedy on the relations between Islam and the West, particularly the United States of America, see Osman Bakar, "The Impact of the American War on Terror on Malaysian Islam", Islam and Christian-Muslim Relations 16, no. 2 (April 2005), 107-27.

2. Actually as early as 1992, almost a decade before the tragic events of September 11, we have already often encountered such a negative testimony of Islam and its followers. In a paper entitled "Toward a Better Appreciation of Islam in the West", which I presented at a 1992 conference in Kuala Lumpur on "Islam and the West" jointly organised by the Institute of Islamic Understanding Malaysia (IKIM) and the United States Embassy, I referred to my personal encounter with an American scholar who believes Islam is incompatible with pluralism, because "everywhere Muslims are fighting everyone else". However, his encounter with Islam in Malaysia persuaded him to review his estimation of Islam and the Muslims. "The Malaysian experience of Islam", he says, "shows that Muslims not only can coexist peacefully with others, but also can govern a modern pluralistic society." For my reference to this illustrative encounter, see Osman Bakar, Islam and Civilizational Dialogue: The Quest for a Truly Universal Civilization (Kuala Lumpur: University of Malaya Press, 1997), 38-9.

3. Bernard Lewis is presently the Cleveland E. Dodge Emeritus Professor of Near Eastern Studies at Princeton University. He has published numerous books and articles on Islam and the Islamic world in the last 50 years. His first publication which brought him international fame was The Emergence of Modern Turkey (1961). Other well-known publications include The Crisis of Islam: Holy War and Unholy Terror (2003), What Went Wrong: The Clash Between Islam and Modernity in the Middle East (2002), Islam from the Prophet Muhammad to the Capture of Constantinople (1987, 2 vols), The Muslim Discovery of Europe (2001), and The Jews of Islam (2000). 
known critic of Islam whom some have referred to as the 'doyen of Middle Eastern studies in America', and the person who coined the term 'clash of civilisations' later borrowed and further developed by Samuel Huntington, and also the intellectual architect of George Bush's war on terror, has described the September 11 attack to Michael Hirsh, a senior editor at Newsweek, in the following words: "I have no doubt that September 11 was the opening salvo of the final battle." ${ }^{4}$ Those who are familiar with Lewis's decades-old intellectual perspectives and ideological position on Islam would readily agree that, by the final battle, he means the last battle in the civilisational war between Islam and the West.

Lewis's basic premise in his dealing with the Islamic world, as Hirsh puts it, "is that the West - what used to be known as Christendom - is now in the last stages of a centuries-old struggle for dominance and prestige with Islamic civilisation". ${ }^{5}$ In line with this basic premise as well as the premise that Bin Laden is a mainstream expression of Muslim frustration at the West energised by Islam itself, Lewis advocated both a military and an intellectual response to September 11. Militarily, there has to be "a decisive show of American strength in the Arab world". ${ }^{6}$ Given its strategic position, Iraq was then the obvious choice as the target of a twenty-firstcentury Western conquest to end the civilisational war. Intellectually, there has to be a remaking of Islam, modelled after Kemalist Turkish Islam. The chief instrument needed for this remaking would be an 'Islamic Reformation'.

The Lewisian belief is that Islam is incompatible with modernity, political democracy, and cultural diversity and pluralism, the very things considered as the hallmarks of modern Western civilisation. As the belief goes, only a radically reformed Islam can come to terms with these modern Western achievements. Lewis is no doubt an important intellectual figure in the Western discourse on Islamic reforms. The issue of Islamic reforms and Lewis's engagement with it predates September 11. Calls for Islamic reform, from both Muslims and Westerners, have been heard since as early as the turn of the nineteenth century. As we have seen over the decades, these voices tend to be louder whenever there is a catastrophic event involving Islam or the Muslims and the West. The more catastrophic the event is, the louder the voices for reform would seem to be. The September 11 attacks were a catastrophe watched by the whole globe for days and days thanks to its daily replays by television channels around the world. In response, many voices, amplified by the media targeted Islam and the whole Islamic world for reforms. The loudness of these critical voices seemed to be proportionate to the destructive impact of the attack. Likewise, even the more recent interest of Western scholarship in the

4. See Michael Hirsh's article "Bernard Lewis Revisited", Washington Monthly (November 2004), available online at http://www.washingtonmonthly.com/features/2004/0411.hirsh.html (accessed on 8 April 2009). Hirsh is also the author of At War with Ourselves: Why America is Squandering its Chances to Build a Better World (New York: Oxford University Press, 2004).

5. Hirsh, "Bernard Lewis Revisited".

6. Ibid. 
modern Muslim experience of diversity and pluralism could be observed well before September 11. But it was September 11 and the ensuing American-led invasion of Afghanistan and Iraq, particularly the latter, that produced the most politically significant phase of Western discourse on the issues of Islam and democracy and pluralism ever conducted.

There could not have been a more politically significant development in the history of the international community of modern and sovereign nation-states than the spectre of a military conquest of one of its Muslim members by the lone superpower member with the purported objective of implanting a Western-style democracy for its people and transforming it into a secular, pluralistic state with only a minor role for Islam. Adding further significance to the September 11 discourse is the fact that some of the discussants, including Lewis, were not just advocates of Islamic reforms; they also supported Islamic and democratic reforms through military conquests just like what America and her allies have done in Iraq. Of course, in the case of Lewis, as Hirsh has clearly shown, he was more than a mere supporter of the invasion of Iraq. He was the chief ideologue of the Iraq war, providing its intellectual justification.

Yet another significance of the post-September 11 discourse is the growing criticism of the Lewisian belief in the West, among both Muslims and non-Muslims. From the critics' point of view, this belief, widespread though it may be, is rather erroneous. It is gratifying to note that this belief is now being challenged more widely in the West itself. We also know of many American academics, scholars, and think tanks who, while still unsure or even sceptical of the 'real' Islam, took the admirable steps of trying to verify this belief. They wanted to find out for themselves the truth of the matter: whether the conflict-ridden relations between many mixed Muslim and non-Muslim communities could be attributed to the teachings of Islam, or whether they are the result of some other factors that Muslims in due course can overcome.

Of specific interest to us in this article is that aspect of the Western belief, best represented by Lewis, which argues for the reforms of Islam if it is to succeed in dealing with modernity and diversity and pluralism. It is my intention here to provide an Islamic critique of this aspect of the Lewisian belief. For this purpose, I will refer in particular to the post-September 11 conversation between Lewis and Khaled Abou El Fadl, ${ }^{7}$ an Arab-American scholar of Islamic Law, on the subject

7. Khaled Abou El Fadl is presently the Omar and Azmeralda Alfi Distinguished Fellow in Islamic Law at the University of California at Los Angeles (UCLA). Among his books are Rebellion and Violence in Islamic Law (Cambridge: Cambridge University Press, 2002), The Place of Tolerance in Islam (Boston: Beacon Press, 2002; also contributed by Tariq Ali, Milton Viorst, John Esposito and others), Conference of the Books: The Search for Beauty in Islam (Lanham, MD: Rowman and Littlefield, University Press of America, 2001), and The Great Theft: Wrestling Islam from the Extremists (San Francisco: HarperOne, 2005). 
of "Islamic Reformation" because of its great relevance to the core issue of our discussion. September 11 and its aftermath catapulted Abou El Fadl to national prominence among the scholars of Islam in America, because he was perceived as a voice of reason and progressiveness in matters Islamic. It is particularly his critique of the so-called Islamic Puritanism that endeared him to Western academia. The debate between the two academics was convened by Global Policy Exchange, a Washington DC think tank, and was entitled 'A Conversation on the Theme "An Islamic Reformation?""8 That the chosen theme of the conversation was "Islamic Reformation' so soon after September 11 is highly significant: it points to a conscious attempt in the minds of some people in influential circles to paint a deep connection between the tragedy and Islam. It suggests that Islam has a causal role in the tragedy. This means that Islam is in need of a real change and transformation. The chosen theme lends credence to my earlier assertion that, in accordance with the Lewisian belief, the remaking of Islam is synonymous with an 'Islamic Reformation'. But then the question mark in 'An Islamic Reformation?' also suggests uncertainty in the minds of the same people about the feasibility of a Western-type reformation in the case of Islam.

\section{Islamic Reform: An Internal View}

In her introduction to the Lewis-Abou El Fadl conversation, Tovah LaDier, president of Global Policy Exchange made very clear to the audience the reason for her think tank's deep interest in the issue of Islamic reformation and renewal. Explaining that the debate marked the opening event of one of its major projects, "Islam and the West in the 21st Century: Reformation and Renewal", she spoke of the project's attempt to study

Islam's adaptation to what we view as a major concern of our time, and that is the acceptance of diversity as a precondition for international peace and security. Many issues are part and parcel of this adaptation: political and economic reform, the relationship between religion and the state, gender equality, health care, education.

She went on to speak of the still unresolved question: "What role do the United States and the West have in encouraging Islamic societies to embrace diversity and pluralism in the modern world?" We may conclude from her remarks that Islam's

8. The debate took place at the National Press Club, Washington DC, on 18 October 2002, that is, just a year after the September 11 tragedy, which quite obviously served as a very important background to the conversation. A transcript of the conversation along with responses from the audience under the same title is available online. The following year, I was invited by Mrs Tovah LaDier, president of Global Policy Exchange, to give a written response to the conversation for publication. I have utilised a substantial portion of that response for the purpose of writing this article.

9. The italics are mine and draw readers' attention to the major underlying concern of the conversation, namely how to encourage the Islamic world to embrace diversity and pluralism in today's world. 
failure to adapt to the modern world is a major concern of the West; Islam's failure to embrace diversity and pluralism is a threat to international peace and security. The necessary adaptation calls for a thorough societal reform. In her view, the West must seek ways and means of how to encourage the Islamic world to embrace diversity and pluralism.

It was in light of her remarks and questions raised by the moderator, Gerald Seib of The Wall Street Journal that both Lewis and Abou El Fadl tried to discuss quite a good range of issues pertaining to contemporary Islam and its relations with the West. The issues discussed include the perceived clash of civilisations between Islam and the West, whether democracy will lead to Islam's reformation, Islam and freedom, and Islam and human rights. Undoubtedly, all the issues raised and discussed are important to both sides of the civilisational divide, although it is not quite clear if Muslims and Westerners attach the same degree of importance and significance to each of the issues debated. Given the acute importance of relations between Islam and the West for global peace now and in the future, any conversation that seeks to address outstanding issues clouding those relations is most welcome. While admittedly there have been a few fresh insights from Professors Lewis and Abou El Fadl into the understanding of the issues concerned, I do not think that the issues have been treated in sufficient depth to do justice to the general theme of the conversation. The very important question of whether or not the majority of Muslims want to have a Western-style religious reformation as Christianity has gone through was not even raised and theologically and empirically examined.

Given the idea of 'Islamic reformation with a question mark' as the general theme of the conversation, it is surprising that both Lewis and Abou El Fadl did not bother to make concrete responses to the term 'Islamic Reformation'. I grant the fact that some of the ideas they brought up, especially those coming from Lewis, are relevant to the subject of Islamic reformation. I mean, for example, Professor Lewis's idea of distinguishing between Islam as a religion and Islam as an extremely diverse culture or as a civilisation. Not that this is a novel idea among students of Islam, but when he asserts that the distinction is important, we tend to agree. In the context of discussing Islamic reformation, if we have pursued the idea of the distinction to its logical conclusion, then we should be asking this question: Which reformation do we have in mind, reformation of Islam the religion or reformation of Islam the culture and civilisation? This question needs to be addressed if we are interested in the possibilities of reforms in the house of Islam and if we want to debate the issues of Islamic reforms in their correct perspectives.

In the Islamic world itself, at least in some parts of it, there are currently discourses and debates going on pertaining to the issue of reforms and renewals, including the question of civilisational renewal. As an illustrative example, a major project

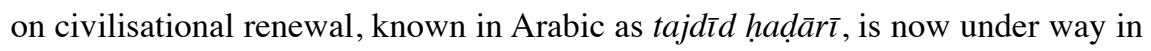


Malaysia at one of its think tanks, the newly established International Institute of Advanced Islamic Studies (IAIS) under the patronage of former Prime Minister Abdullah Ahmad Badawi. ${ }^{10}$ Dr Mohammad Hashim Kamali, the Chairman and Chief Executive Officer of IAIS who is also one of the world's leading scholars in the field of Islamic Law, has written a work explaining the philosophy and

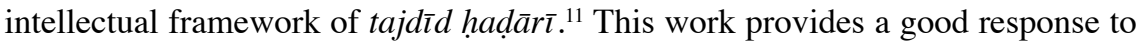
the Lewis-Abou El Fadl conversation on Islamic reformation. The civilisational renewal of Islam as envisaged by IAIS embraces Islam's positive approach to the issue of diversity and pluralism, which is a different picture from the one depicted by many of its Western critics. As a matter of fact, the protection of minorities is one of the ten principles of Badawi's 'Islam Hadhari'. ${ }^{12}$

Equally important in Lewis's presentation is his pointing to Islam as having an internal religious structure that fundamentally distinguishes it from Christianity. Again he does not proceed to discuss its implications for Islamic reforms, at least not in this particular conversation. A major implication of this fundamental difference between the two religions in their internal structures is that the possibilities of reforms are bound to be different in the two religious traditions as amply demonstrated in history. The notion of reform necessarily takes different meanings and forms in the two religious traditions, although certain commonalities are entirely possible. It would then be unreasonable to expect Islam to produce the same kind of religious reformation as Western Christianity had done, not even in the more limited domain of Islam the culture.

There is another important implication that we should not lose sight of, especially by Westerners keen on helping to bring about genuine reforms in Islam. While external forces, including those coming from the West, can inspire and even shape reforms in Muslim societies, ultimately what proves to be decisive in determining the lasting efficacy of these reforms would be the factor of their compatibility with Islamic teachings. This means that, for example, democratic reforms and the cultivation of democratic values in Muslim societies have to be sustained and nourished by their Islamic roots, although their external forms may be borrowed from the modern Western democratic traditions. Thus many Malaysian Muslims have argued that while the external forms of their parliamentary democracy have been based on the British Westminster model, the essence of that democracy, namely

10. Abdullah Ahmad Badawi has adopted 'Islam Hadhari', meaning 'Civilisational Islam', as the 'Islam Policy' of his administration (2003-09), by which IAIS has been partly inspired. One of its concerns is how to understand and present 'Islam Hadhari' in universal terms and explore the depth and breadth of its intellectual content. See Mohammad Hashim Kamali, IAIS Malaysia: Exploring the Intellectual Horizons of Civilisational Islam (Shah Alam: ARAH Publications, 2008).

11. See Mohammad Hashim Kamali, Civilisational Renewal: Revisiting the Islam Hadhari Approach (Shah Alam: ARAH Publications, 2008). I have written a foreword to this book (v-ix).

12. Kamali, IAIS Malaysia, 47-51. 
the idea of popular representation and democratic pluralism in the running of the affairs of the multi-ethnic and multi-religious nation, is inherently compatible with the qur'ānic principles of shura (consultation) and social justice for people of all faiths and ethnic backgrounds.

My point of emphasis in the foregoing discussion is that while some of Lewis's ideas are relevant to the debate on Islamic reforms, the concept of reformation has not been specifically addressed. My view is that the concept should have been well defined and explained in the first place since it is central to the whole conversation. Without defining and clarifying the concept we would lack clarity in the presentation of issues that really matter in our discourse on the possibilities of reforms in Islam. Moreover, the idea of an Islamic reformation is a controversial and emotionally charged issue in contemporary Muslim societies, partly because the contours of the debate have not been well defined. Quite clearly, there are many Muslims out there who are so conservative in their thinking that they refuse to entertain even the slightest idea of religious reform. But even among the reform-minded Muslims, especially those familiar with the history of religious reforms within Christianity, the majority of them do not favour reforming Islam in the same way and to the same extent Christianity has been reformed. For one thing, they just think it is not possible to follow the footsteps of Western Christian Reformation by virtue of the nature and internal structure of Islam as a religion. Does this mean Islam is beyond reforms and that Muslims are condemned to live by unchangeable religious traditions at all times? Absolutely not! There are many other Muslims with the strong opinion that Islam is fully capable of reforms simply because the fundamental sources of the religion are not empty of ideas relevant to the pursuit of internal reforms.

In my view, the most powerful idea in Islamic tradition pertaining to reforms

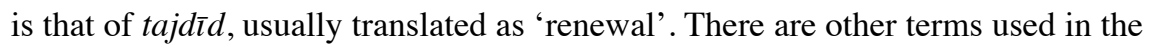
contemporary Muslim discourse on reforms, words such as iṣlạh and nahdah. The word nahdah appears, for example, in the name of Indonesia's biggest Muslim organisation the Nahdatul Ulama (NU) formerly led by Abdul Rahman Wahid, a former President of the Republic, which was established with the aim of defending Islamic spiritual traditions in the country. The word $i s l a ̄ h$ is an even more popular word, especially among Muslim modernists and activist-members of contemporary self-styled Islamic movements (al-harakat al-islämiyyah). In my view, however,

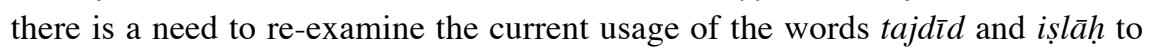
ensure that our understanding of religious reform is in complete conformity with Islamic perspectives. In this new understanding we are required to take into account all the elements and dimensions that make up a veritable Islamic reform, carefully situating them in their proper contexts and giving them their respective true worth. We are aware of the views of certain scholars who insist on making a fine distinction

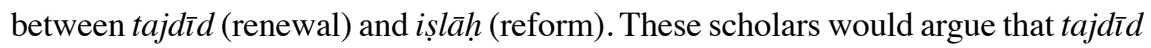


necessarily involves a programme of spiritual and moral renewal or inner transformation of individual Muslims under the spiritual and intellectual leadership of one or more religious scholars, whereas ișlāh is more concerned with reforms of the external aspects of the religion and of the transformation of society such as with its juridical (fiqh) and institutional reforms.

One such scholar is Seyyed Hossein Nasr, an Iranian-American who has served since 1984 as University Professor of Islamic Studies at George Washington University. Speaking of those with an authentic understanding of the idea of reform, Nasr writes:

This group believes in inner revival (tajdid), which is a traditional Islamic concept, and not external reform (iṣlāh), which is a modern idea grafted upon the body of Islam. The model for this group is an al-Ghazzālī, an 'Abd al-Qādir al-jīlānī or a Shaykh Aḥmad Sirhindī, and not some nineteenth-century or twentieth-century leftist revolutionary who would simply be given a Muslim name. This group acts without acting, in the sense that its function is more that of knowledge and presence than of action. But it is from this group that there has flowed and continues to flow some of the most profound and religiously significant Islamic responses to the modern world. And it is this group that in the long run will leave the deepest effect upon the Islamic community, as has ever been the case in the past..$^{13}$

Nasr and other traditionalists are against the modern idea of reform "which always begins with the outward: which wishes always to reform the world but never man himself". ${ }^{14}$

But in my view, of all the terms used to convey the idea of reform and related ideas like revival, restoration, renaissance and awakening, the most pertinent to our

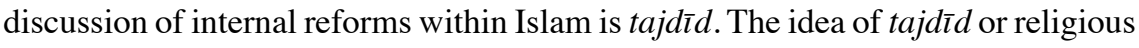
renewal is perhaps the most intrinsic to the Islamic tradition, and at the same time the most explicit in conveying the idea of the necessity of periodic changes to the understanding of religion in the light of permanence.

According to a saying of the Prophet Muhammad, "God will send to this community at the turn of each century someone [or 'people'] who will restore [revive/renew] the religion" (Inna 'llāh $h^{a}$ yab' ath ${ }^{u} l i$-hädhih ${ }^{i}$ 'l-ummat ${ }^{i}$ alā ra's ${ }^{i}$

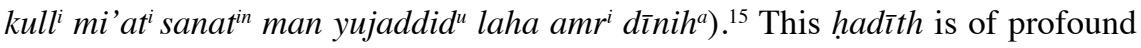
significance for the discussion of Islamic reformation. Strangely enough, it is seldom

13. Seyyed Hossein Nasr, Traditional Islam in the Modern World (London: Routledge and Kegan Paul, 1987; repr. Kuala Lumpur: Foundation for Traditional Studies, 1988), 92.

14. Ibid.

15. Sunan Abū Dawud, Book 35 (Kitāb al-fitan wa'l-malāhim), chapter 1. For an extensive modern discussion of the Muslim understandings of this hadīth over the centuries, see Ella LandauTasseron, "The Cyclical Reform: A Study of the mujaddid hadīth", Studia Islamica 70 (1989), 79-117. 
mentioned even by those Muslims who love to talk about the need for a reformation in Islam. Yet it is a powerful argument against religious conservatism and all forms of extremism and deviationism in favour of an authentic religious renewal. I would like to offer my own understanding of this significant hadith with the hope that we can draw important conclusions from it.

The early and traditional interpretation of this hadith emphasises the idea of individual mujaddid $^{16}$ (renewer/restorer/revivalist) being inspired by God to perform the task of $\operatorname{tajd} \bar{d} d$ (renewal/restoration/revival) of the religion of Islam. Many well-known scholars and public leaders in the history of Islam have been widely acknowledged as belonging to this honourable group of the mujaddidūn (plural of mujaddid). ${ }^{17}$ The more modern interpretation, however, seems to favour the idea of tajdi $d$ as being a collective undertaking. With the difficulty of identifying an individual figure from among the scholars of Islam - the 'ulam $\bar{a}$ ' - as the sole mujaddid of the century, if at all it is possible to do so, it is understandable if some scholars of religious reform within Islam feel more comfortable talking

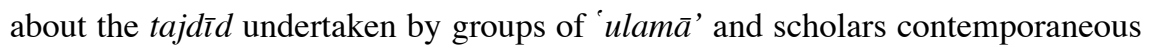
to each other.

We see two main conclusions that can be drawn from the above hadīth. The first conclusion is that the necessity of religious renewal is acknowledged. Second, the renewal has to be periodic, thus implying that new circumstances will crop up from time to time that will necessitate a fresh interpretation of the religion or institutional reforms. Let us deal with the first conclusion. The Prophet's acknowledgement of the necessity of religious renewal is very important. Words from him, the most important for the Muslims after the Qur'ān, are authoritative like no other Muslim pronouncements on reforms, and therefore can be highly consequential on the Muslim masses. We can understand why in the exceptionally large body of the Prophet's sayings and actions, somewhere he has to raise the issue of religious renewal. A religion that does not undergo a renewal is a religion in progressive decline that is on the sure path to its own death.

Of course the question that is left wide open here for interpretation and resolution is which aspects or elements of the religion need to be renewed. It is only to be expected if Muslims are divided in their responses to this question. To be so divided is not in itself a bad thing. On the contrary, to have a pluralistic interpretation of

16. The Arabic word mujaddid means someone who restores, revives or renews something, in this case religion $(d \bar{\imath} n)$.

17. Abul Hasan Ali al-Nadwi, a leading Indian Muslim scholar of the twentieth century, has included in his selected list of mujaddidūn such distinguished personalities of Islam as Abū 'l-Hasan alAsh arī, al-Ghazzālī, Salāḥ al-Dīn al-Ayyūbī (known in the West as 'Saladin'), Ibn Taymiyyah, and the mystical poet Jalāl al-Dīn Rūmī. See Nadwi's Saviours of Islamic Spirit, ed. and tr. Mohiuddin Ahmad, 3 vols (Lucknow: Academy of Islamic Research and Publication, 1976; repr. Karachi: Darul Ishaat, 1994). 
religion at the hands of knowledgeable people is a good thing, so the Prophet said. "Differences of opinions among knowledgeable people are a mercy to the community", says a hadīth. Professor Lewis has also quoted this prophetic saying when emphasising the diverse and pluralist nature of Islamic society and civilisation in the past. Such an appreciation of pluralistic interpretations of religion would be completely consistent with Islam's spiritual democracy and its internal structure that gives rise to its claim as being the most democratic of all the world's religions. Quite obviously, more so when judging from present-day Muslim attitudes toward pluralism within Islam itself, this precious message of Islam appears to have been lost or ignored by the great majority of Muslim communities the world over. Only the enlightened Muslim minds seem to take joy in quoting this hadīth while the rest pretend it does not exist!

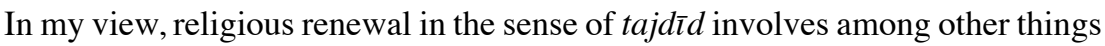
the re-discovery of timeless wisdom that for one reason or another has been lost in the stream of time like the one just mentioned but re-interpreting and re-living it in the light of contemporary conditions. Tajd $\bar{l} d$ is about renewing the religion without destroying its original soul, spirit and character. This may be realised through the careful differentiation of the religion's permanent elements, be these ideas or ritualistic forms, from its changing elements and striking a delicate balance between the two types of elements. Tajdi $d$ can very well involve the borrowing of ideas and institutions from other cultures which are then integrated into its worldview and socio-cultural system. In our own times, the Muslim borrowing of political ideas, institutions and processes from Western democracies may be cited as an example of issues that pertain to this aspect of tajdīd. Another good example would be the borrowing of elements from the modern Western scientific and technological culture just as the West once borrowed from the then superior Islamic scientific and technological culture. There is nothing to be ashamed of in these kinds of cultural borrowing. Muslims who repudiate them and slam the door of Islam to what is good from other cultures only invite charges of ignorance of history including their own and the nature of inter-civilisational encounters and relationships. Far worse, they invite charges of infidelity to the many universal teachings of their own religion.

It is very clear then that as a whole the tajd $\bar{\imath} d$ enterprise necessitates a lot of intellectual effort and work for it to succeed. Indeed, the core of tajdī $d$ is the production and advancement of new intellectual ideas. In the light of all these remarks about tajdi $d$ it is not surprising if this idea of reform finds few serious proponents. Not many people want to do serious thinking. There have been a lot of calls for reforms of Muslim societies from the four corners of the Muslim world not to mention from the West itself, but actual reformers are rare to find. It is one thing for a Muslim scholar, thinker or intellectual to call for an Islamic reform and 
to dwell on its necessity, but it is another to actually come up with the reform itself by having the necessary ideas and societal mechanisms to pursue that reform to its successful conclusion. What we need most at this particular hour of Muslim history is precisely a lot of serious intellectual thinking among Muslims to produce veritable ideas that can help clarify the meaning of Islamic renewal in the context of contemporary global conditions.

\section{Is There Room for Optimism?}

Given the present malaise of the Muslim ummah, is there room for optimism? Is

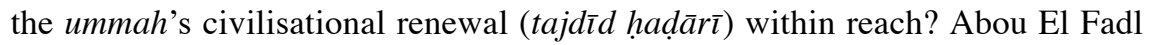
has rightly criticised Muslim thought of the past century or more for being mostly reactive to the modern West and its civilisation, by which he means it is either apologetic or 'rejectionistic' in orientation. A general survey of the contemporary intellectual landscape in the Muslim world tends to support his view. Save among a few scholars, it is difficult to find proponents of an intellectual "middle ground" that does full justice to both Islam and the West. The middle ground - neither apologetic nor 'rejectionistic' - is actually the best hope of the twenty-first century in realising better relations between Islam and the West. Intellectually speaking at least, it is in the best position to promise a new era of greater mutual respect and honour between the two sister civilisations, provided the West too is committed to keeping its side of the civilisational deal.

On the Muslim side, they should not be apologetic about their religion and civilisation, ever eager to demonstrate the compatibility of Islam with everything that is Western. Instead, they should present themselves in their own terms. Islam is a distinct religion and as such it is bound to produce a distinct civilisation. Islam does indeed have civilisational differences with the West, but there are also plenty of similarities and resemblances between them. Muslims have a right to be religiously and culturally different just as Westerners and others have theirs. Moreover, they can and indeed should be proud of all the cultural differences in question. This is one of the meanings of living together in a world of cultural diversity and pluralism.

Muslims should also do away with the tendency to reject everything that has originated from the West. Such a tendency is contrary to the spirit of Islam. The Qur'ān is inclusive in its spirit, viewing truth and knowledge in all forms as the common property of all humans regardless of their origins. It is in the light of the Qur'ān's universal perspectives on truth and knowledge that we encounter in Islamic history a lot of borrowings and adoptions from other cultures and civilisations of both the East and the West. It was these cultural borrowings that had enriched Islam in the past. Muslims need to realise that in many domains of human life and thought the most creative civilisation today is that of the West. It is only reasonable for 
them to learn as much as possible from the West and then attempt to integrate the good things from the West into the cultural and civilisational framework of Islam. Nothing really good can come out of the apologetics and rejectionists! The future of Islamic civilisation would depend very much on the success of those Muslims who are pursuing the 'middle ground'. In general terms, it may be said that the success of the ummah's civilisational renewal in the twenty-first century would depend very much on the restoration of its identity described by the Qur'ān (2:143) as ummat ${ }^{a n}$ wasat ${ }^{a n}$ ('community of the middle path'). The restoration of the spirit embodied in the qur'ānic principle of wasatiyyah ('moderation and balance') ${ }^{18}$ has to appear as a key item in the agenda of Islamic reforms and renewal.

\section{Diversity and Pluralism: An Islamic Response}

While insisting on their right to be culturally different from the West and calling on the West to respect that right, Muslims are also called upon by their own religion to celebrate their civilisational similarities with the West. Lewis believes that past civilisational conflicts between Islam and the West have originated more from their similarities than from their differences..$^{19}$ Lewis's position on this point is arguable, but it seems to me the Qur'ān is very positive about the role of cultural similarities in bringing together people of different beliefs and diverse cultures. I know many Muslims informed by the Qur'ān and their interpretation of Islamic history would disagree with him on the above issue in question. However, the present reality in Muslim societies seems far removed from the ideals envisioned by the Qur'ān. As if lending credence to Lewis's view, the great majority of today's Muslims are talking more about their differences with the West than with their similarities. But the same thing can be said about Westerners in their view of Muslims. While Muslims share many values and civilisational aspirations with Americans and Europeans, what the latter two geo-cultural groups tend to emphasise is their differences with Muslims.

If we are viewing the current relationship between Islam and the West, we can say that it is thickly clouded by the politics of differences that has been pushed to the centre stage, relegating the politics of similarities to the periphery. What the Qur'ān

18. For a good discussion of this qur'ānic principle and its significance to the civilisational renewal of Islam, see Mohammad Hashim Kamali, "The Middle Grounds of Islamic Civilisation: The Qur'ānic Principle of Wasațiyyah”, IAIS Journal of Civilisation Studies 1, no. 1 (October 2008), $7-41$.

19. Lewis believes in the idea of 'clash of civilisations', which, he says, has happened in the past and is observable at present. He is referring specifically to the clash of civilisations between Islam and the West. What he does not believe in is the idea of 'alliance of civilisations'. He says: "What I can't see is civilizations forming alliances, conducting foreign policies, making alliances, making war, and so on. That, I must say, I find a little difficult to swallow." See Lewis and Abou El Fadl, A Conversation. 
would like to see prevailing in the world community is the very opposite, namely the predominance of politics of similarities over politics of differences. The rationale of the Qur'ān's position on this matter is very simple: in truth, human beings, human cultures, and human civilisations have much more fundamental similarities than they have fundamental differences. To put it another way, cultural similarities are viewed as more fundamental in nature than cultural differences.

The Qur'ān does not ignore differences that tend to divide humanity, especially those that are in conformity with the nature of things. However, differences that manifest themselves in the form of what we nowadays like to call diversity and pluralism are evaluated and judged by this sacred book in a very different light, namely in the light of human similarities. ${ }^{20}$ In this light, the Qur'ān appeals to the deep reservoir of our common humanity and our larger common interests and goals as members of a single world community to furnish us with the inner resources needed to overcome the challenges that the world's diversity and pluralism had posed to global peace. Similarities are the most appropriate things to serve as the starting point and as the common basis for negotiating differences and cultivating mutual respect over irreconcilable differences.

The phenomenon of cultural diversity and pluralism in our world is nothing new. Neither is the human societal consciousness of this phenomenon something new. Lewis alludes to the fact that in classical Islamic tradition diversity was very much accepted as a way of life. Indeed, in the most creative and enlightened period of Islamic history many centuries ago, the idea of diversity and pluralism was widely discussed at various levels, including the theological, philosophical and legal-political. Moreover, the idea was not only discussed out of intellectual concern and curiosity but also out of practical needs in societal life particularly in the domain of religion, law, and politics. The idea of diversity and pluralism is explicitly mentioned in a number of places in the Qur'ān. It was to the great credit of the Muslim theologians, political philosophers, and jurists of the past that they had sought to formulate various human perspectives on both the theoretical and practical meanings and significance of the idea. Muslims today can look back to that enlightened era of their history and draw inspiration from it.

Theologians of various schools of thought wrote works on the theme of religious diversity and pluralism. They also discoursed and debated with each other on the subject. There was a theological acceptance of religious pluralism not only within Islam but also outside of Islam. Islam appeared to be far more inclusive then than now in its acceptance of other religions, although in comparison with many other

20. For a discussion of the Qur'ān's treatment of the theme of similarities and differences between religions, cultures, and civilisations, see Osman Bakar, The Qur'an on Interfaith and InterCivilization Dialogue: Interpreting a Divine Message for Twenty-First Century Humanity (Kuala Lumpur: International Institute of Islamic Thought, Malaysia (IIITM) and Institute for the Study of the Ummah and Global Understanding (ISUGU), 2006). 
religions including Christianity, even now its inclusiveness is still unsurpassed. Interpreters of Islamic law, as in the domain of theology, spoke of legal pluralism both within Islam and beyond. Islam's inclusiveness in law manifested itself in the recognition of the rights of other religious ethical-legal systems to exist and function within Islamic polities. It also extended the sources of Islamic law to include certain laws based on the scriptures of other religions or what the Qur'ān calls 'the people of the Book', and pre-Islamic local traditions and customs. The validity of other religious laws and pre-Islamic local customary laws was accepted as long as these are not opposed to the teachings of the Qur'ān. For example, in the Malay-Indonesian world, native customs known in Malay as adat (from Arabic $\bar{a} d a h)$ were accepted as an important source of Islamic law, although, admittedly, tension has always existed between certain elements in the adat and the shari $a h$.

Clearly then, there was a greater tolerance of diversity and pluralism in the Muslim distant past than there is now. On the basis of this historical fact alone, one cannot justifiably make a claim that the West has been the most enlightened and the most progressive in dealing with diversity and pluralism, if we were to understand the latter in a broad sense. One can only accept the above claim in a more limited context, that is, if it were to be confined to the modern period and even then to only certain types of pluralism, particularly democratic pluralism. It is arguable, for example, that the United States of America has been far more successful than say Malaysia in managing ethnic pluralism over much of their respective histories as independent nations. Clearly, Malaysia had an early lead in the 'competition'. When upon independence in 1957 Malaysia practised parliamentary democracy that gave equal voting rights to its citizens of all ethnic groups, men and women, and implemented an ethnic-based power sharing formula unique in the world, America was still steeped in racism and the battles for the civil rights of its blacks and other minorities were still being fought on its streets. But thanks to a number of factors the United States has long captured the lead from Malaysia. In my view, the most important of these factors is democracy.

Although on the whole ethnic relations in Malaysia have continued to improve over the decades, progress has been slow. In areas like inter-faith dialogues there has been very little progress. The main reason for this is that ethnic and religious relations in the country are almost wholly managed and regulated by the state. The nation's leaders, both political and religious, are either uninterested in such kinds of dialogue or tend to discourage them on the ground that Malaysians are not yet ready to dialogue on sensitive matters like religion. ${ }^{21}$ They do not want to see ethnic

21. In the past, there have been a few exceptional interests on inter-religious and inter-civilisational dialogues coming from the political leadership such as the one shown by Anwar Ibrahim, a former deputy Prime Minister, when he served under Mahathir Mohammad. In the 1990s, Anwar Ibrahim had patronised inter-religious dialogues, particularly involving the Malays and the ethnic Chinese who form the two biggest ethnic groups in the country. 
and religious grievances, especially coming from non-Malays and non-Muslims to be discussed in the open. In today's Malaysia we may consider Abdullah Badawi and Anwar Ibrahim as having made significant contributions to the country's better appreciation of ethnic and religious pluralism and democracy. Abdullah Badawi will be remembered in Malaysian history as unleashing new forces for greater democratisation in the country. As he leaves the corridors of power he makes clear that Malaysia should not return to the authoritarianism of the Mahathir era. As for Ibrahim he strongly believes that it is time for Malaysia to open a new chapter in its history of ethnic relations by promoting inter-religious dialogues, and that Malaysians are intellectually ready to venture into such cultural activities, just as he feels the country is ready for greater democratisation in disagreement with Mahathir. But Abdullah Badawi's and Anwar Ibrahim's patronisation only goes to illustrate the point that, in Malaysia, without support from top political leaders it is doubtful the practice of diversity and pluralism could move forward beyond the level of peaceful co-existence currently observed.

Still, despite its many shortcomings, Malaysia's achievement in ethnic relations has been noteworthy. Moreover, there are other bright spots here and there in the Islamic world pointing to modern-day Muslim achievements in coping with cultural diversity and pluralism. But there are Muslim regions that are rife with sectarian conflicts along religious and ethnic lines, a situation amounting to a betrayal of the qur'ānic celebration of diversity and pluralism. Generally speaking, taking all kinds of pluralism into account - ethnic, religious, intellectual, and democratic - it seems to be true that the greater part of the contemporary Islamic world lags far behind the West in managing diversity and pluralism within its national borders.

Without going into the factors that have brought the Islamic world to its present state of affairs, which are many and complex, internal as well as external including those originated by the West, let me come back to the issue of tajdi d. Regardless of those factors, we do know there has to be a vast improvement in the appreciation, articulation and management of pluralism in the Muslim world. And in my view,

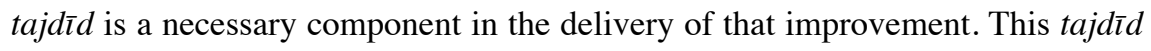
has to be primarily concerned with the articulation of a new understanding of the meaning and societal demands of pluralism both within and beyond Islam. The qur'ānic ideas about diversity and pluralism have now to be reinterpreted in the light of prevailing situations in Muslim societies and our contemporary world.

Obviously the world has changed so much as to necessitate such a reinterpretation. An entirely new phenomenon for the whole world to see is the presence of Muslim minorities in practically every country in the West. These Muslim minorities, living as they are in pluralistic Western societies, are also in urgent need of this new Islamic interpretation of cultural diversity and pluralism, certainly no less than the need of their brethren in Muslim majority countries. We do not think we have right now a 
Muslim minority that can serve as a model for all Muslim minorities in the world, successful in projecting its Muslim community identity and discharging its duties and responsibilities as a minority and at the same time at peace with the majority community as well as with other minorities living under the same national roof. Quite clearly to be that successful a Muslim minority has to have a new understanding of the Islamic perspectives on what it means to be a religious community in a pluralistic society. We are yet to come across an enlightened treatment of the issue at hand.

But we are also quite aware that, notwithstanding its current appreciation and practice of cultural diversity and pluralism, the West too is yet to produce welldeveloped concepts and theories pertaining to cultural pluralism that would meet the current and future ideational needs of pluralistic societies. Western religious, social, and political thought that does full justice to the subject is found wanting. Whatever ideas we now have at our disposal on this very important subject are insufficient to meet even our present needs. As I pointed out earlier, the Western experience of cultural diversity and pluralism is more recent especially when we compare it to that of Islam. Interestingly, the modern phenomenon of cultural diversity and pluralism associated with the creation of new pluralistic societies all over the world is primarily the creation of the West, more precisely the product of the global agendas of the European colonial powers in the nineteenth and first half of the twentieth century.

In the pursuit of their respective colonial economies during this period, the rival European colonial powers had set in motion wave after wave of migrant workers from one geographical region to another. In consequence, many culturally homogeneous societies in the colonial empires were transformed into pluralistic societies in an unruly way with all the dangers and risks such kinds of societies have the potential of generating. Of all the colonial legacies inherited by the newly independent states, nothing was perhaps more problematic than the burden of managing cultural pluralism. Malaysia is a good example of such states. From being a homogeneous Malay-Muslim nation until as late as the middle of the nineteenth century, it became transformed into a multi-ethnic and multi-religious country upon the arrival of large numbers of ethnic Chinese and Indians as migrant workers to serve the British colonial economy in the country. But Malaysia is fortunate that it has proved more successful than most formerly colonised territories in managing ethnic and cultural pluralism and doing so in the context of a parliamentary democracy that has run uninterruptedly for nearly half a century now.

Many of these formerly colonised territories are Muslim like Malaysia. If Malaysia has been relatively successful in developing and managing itself as a pluralistic society while preserving its predominantly Muslim identity, then this 'success story' needs to be studied as much as we need to study why most of the other Muslim nations with similar historical experiences have fared rather poorly in coping with 
their respective pluralisms. Such a comparative study would be important, because it would help us to be careful not to be hasty in primarily attributing the poor performances of these countries to Islam's structural characteristics. We commend Professor Lewis for pointing out Islam's generally positive record in its treatment of pluralism before modern times. This means that Islam as a religion cannot be faulted for the failures of any Muslim country, although individual Muslim interpretations of the religion's doctrines certainly can. In explaining the failures of some Muslim countries in managing pluralism we need to look closely also at the non-religious factors in the same way we need to pay attention to such factors in accounting for the success of a country like Malaysia.

Following the granting of political independence to their former territories after the Second World War, it was the historic turn of the European motherlands to receive the flow of emigrants mainly from their former colonies. This new emigration of non-whites helped to change the colour of the ethnic composition of European societies, resulting in the formation of new pluralistic societies in the West. In the United States which has a history of emigration patterns of its own, a new consciousness of cultural pluralism was partly enhanced by the growing number of non-white immigrants into the country especially noticeable a few decades ago. Muslim minorities form an important constituent of this new cultural mosaic in the West. As we see it, the West is still struggling to come to terms with this newfound cultural pluralism with all its ethnic and religious minorities just as the latter are trying hard to adjust themselves to their new cultural homes. We would then argue that in this new cultural reality there is room for mutual learning by both the Muslim minority community and the Judaeo-Christian majority community on the meaning of pluralism and the art of living together peacefully in a pluralistic society. A new Muslim understanding of cultural diversity and pluralism that we anticipate to come from a tajdi $d$ in the new century would be as much of interest to the Muslim world as to the West.

\section{Conclusions and Perspectives}

For the sake of a better future for the global Muslim community and for the betterment of the world community at large, there is an urgent need here and now for a new Islamic understanding of diversity and pluralism. However, this new understanding, which is at once traditional and contemporary, can only come about through an authentic tajdī $d$ (renewal) of civilisational proportion that offers fresh interpretation of the religion of Islam without destroying its original spirit and character. The tajdī $d$ in question is not just about the generation of new ideas on the meaning of diversity and pluralism. It is also about how this new understanding can find fresh applications in all domains of human civilisation. Scholars and thinkers dealing with 
issues of civilisation are expected to play a more dominant intellectual role than any other group in providing the core ideas that shape this new Islamic understanding of diversity and pluralism. Studies of contemporary Islam in Muslim countries, particularly at the universities and colleges, need to embrace a true concern with issues of diversity and pluralism within the context of a civilisational renewal.

Since the key to meaningful religious and societal reforms as implied in both

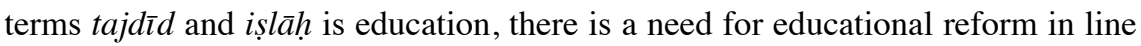
with this new understanding of diversity and pluralism. We hope the new educational reform will facilitate the implementation of the anticipated new understanding of cultural diversity and pluralism inspired by Islam in the nation's schools and universities. Generally speaking, whether a Muslim nation succeeds or not in its management of pluralism will depend very much on the extent of its investment in its national educational programmes and their periodic reforms as necessitated by changing times.

We see that Muslim states that pay more attention to education also appear to be more developed and progressive than Muslim states that do not. In the case of Malaysia, for example, right from the first day of its independence until now, the greatest portion of its national spending always goes to education. Moreover, students of the various ethnic groups, both males and females, study under the same roof. The national system of education is modern, but the emphasis on modern scientific and technological knowledge is always complemented with an adequate concern for the study of traditional religious values and moral systems. I do not think that the positive role of education in serving Malaysia's multicultural needs has been exhausted.

The historic decision by the Malaysian Ministry of Higher Education first to introduce and implement courses on Islamic and other civilisations at universities and later modules on inter-ethnic relations is most welcome. However, this needs further refinement and commitment by the universities to ensure this lauded initiative bears societal fruits that point to a more enlightened theory and practice of diversity and pluralism in Muslim countries.

But diversity and pluralism is not the only issue that a twenty-first-century Muslim tajdi $d$ has to address. Other important issues include the place and role of women in contemporary Muslim societies, Islam and democracy and the related issue of governance, and the place of scientific and technological knowledge in the total body of Muslim knowledge. How the Muslim world deals with these issues is important not only to Muslims but also to the rest of the world, particularly the West. 